\title{
Tumor Regression Score 0
}

National Cancer Institute

\section{Source}

National Cancer Institute. Tumor Regression Score O. NCI Thesaurus. Code C155941.

A score on the Modified Ryan Scheme for Tumor Regression that indicates a complete response, defined as having no viable cancer cells. 